症例

右側腹部帯状疱疹後神経痛に胸腔鏡下胸部交感神経節切除が 著効を示した 1 例

\begin{tabular}{llllllllll}
\multicolumn{10}{c}{ 横浜船員保険病院外科 } \\
河 & 光 & 弘 & 佐 & 藤 & 直 & 中 & 中 & 伸 & 一 \\
古 川 & 祐 & 介 & 今 & 西 & 宏 & 明 & 上 & 妻 & 達 也
\end{tabular}

带状疱疹後神経痛 (postherpetic neuralgia: PHN) は, 難治性疼痛疾患の1つとされ 方。われわれは, 右側腹部の PHN に対して胸腔鏡下胸部交感神経節切除が著効を示した 1 例を経験したので報告する。症例は79歳男性，右側腹部に皮疮が出現し，近医皮成科 にて帯状疮疹と診断され治療を受けていた。，右側腹部痛が増強し経口摄取も不能となり 精榃加療目的に当院入院した。入院時には右側 Th 9 〜h1 1領域体幹に限局した褐色の 皮疮あり，疼痛は同部位が限局していた.PHN と診断したが、鎮痛剤, 持続硬膜外プロ ックでは疼痛コントロールできず, 胸腔鏡下右胸部交感神経節 (Th 9〜Th11) 切除を施 行した，術直後より右側腹部痛は消失した。摘出摽本では神経節細胞の破壊, 神経食現 象 (neuronophagia),リンハ球,形質細胞の浸閏, Cowdry A 型核内封入体を認め varicella-zoster virus：VZVによる交感神経節炎と診断された。

索引用語：带状疮疮後神経痛 $(\mathrm{PHN})$, 胸腔鏡下胸部交感神経節切除, 交感神経節炎

\section{緒言}

带状疮疮後神経痛 (postherpetic neuralgia: PHN) は，難治性疼痛疾患の1つであり様々な治療が試みら れているが，現時点において確実な治療法は確立され ていない. 今回, 右側腹部带状疮疹後神経痛に対して, 胸㬵鏡下胸部交感神経節切除が著効を示した 1 例を経

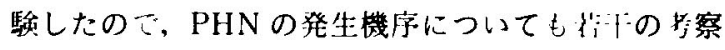
を加えて報告する。

\section{症例}

患者：79荿，男性.

主訴：右側腹部痛。

既往歴：60歳から高血圧にて内服中.

家族歴：特記すべ事なし。

現病歴：1999年.5月29日頃より有側腹部に皮骖出

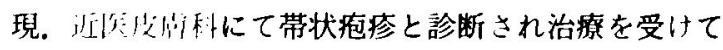
いた。その後, 右側腹部痛が増強し, 経口㨨取不能と なり 6 月30日精李加療目的に入院した。

入院時現症: $159 \mathrm{~cm}, .51 \mathrm{~kg}$, 腹部平坦軟, 有側 Th 9

2000年10月12日受付 2001年 1 月15日採用

〈所属施設住所〉

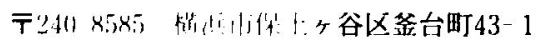

〜Th11領域体幹の皮1周分節に限局した褐色の色素沈 着あり。疼痛, 知覚異常は同部位に限局していた（図 1).

血液学的検查：異常を認めなかった。

入院後経過：PHN と診断し，持続硬膜外ブロック を開始したところ, 疼痛は一時軽快したが, 尿閉, 排 便困難が出現した。局庥漲度調節や patient controlled

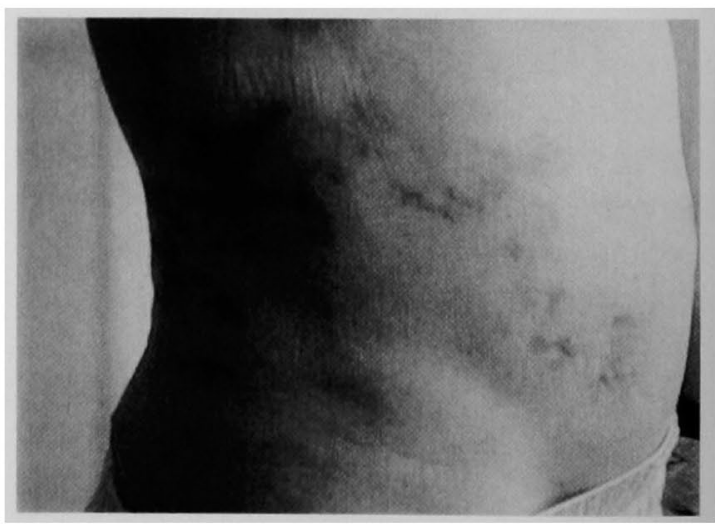

图 1 入院時現症：右側 Th 9 Th11領域体幹の皮庙分 節に限局した褐也の色䒺沈着あり.疼痛, 知覚異常もこ の部位に限局. 
analgesia (PCA 法)を試み, 導尿や浣腸も適宜施行し た.しかし，持続硬膜外ブロックを打ち切ると再び疼 痛は悪化した。内服鎮痛凧, 抗てんかん薬(carbamazepine）も効果十分ではなかった。疼痛が増強したため, 1999年 8 月 1 日胸腔鏡下胸部交感神経節切除を施行し た.

手術所見：分離肺換気下, 左側臥位にて手術を施行 した. 胸腔へのアクセスは $10.5 \mathrm{~mm}$ のポートを 3 力所 に挿入した，胸腔鏡下で，横隔膜より少し頭側の壁側 胸膜を切開し交感神経幹を露出した。金属クリップで マーキング後, 術中 X線写真にて交感神経節のレヘル を確認した上でTh 9, Th10, Th11の交感神経節を切 除した（図 2 ).

病理所見：神経節細胞の破壊, 神経食現象 (neurono phagia）が見られ，リンパ球，形質細胞の浸潤があり 小結節状となっていた(図 $3 \mathbf{a}$ )。また，神経節細胞の 核内に大きい Cowdry A 型核内封入体を認めた（図 3 b ). VZV (varicella-zoster virus)による交感神経節 炎と診断した。

後術経過：術直後より右側腹部の疼痛は, 消失した。 第 5 病日，皮成のチクチクする感覚が出現したが鎮痛 薬は必要としなかった，合併症として，対側の代償性 発汗を認めた。術後 1 力月後頃に疼痛が再燃し, 硬膜 外電極植え込み術も検討していたが，同時期に抗てん かん薬 (carbamazepine) によると思われる薬疹が全 身に出現し皮膚科にてステロイドを使用した。薬疹が 軽快すると共に疼痛も軽快した。現在, 外来経過観祭 中であるが疼痛は再発していない.

\section{考察}

带状疱疮後神経痛 (PHN) は，1986年世界疼痛学会

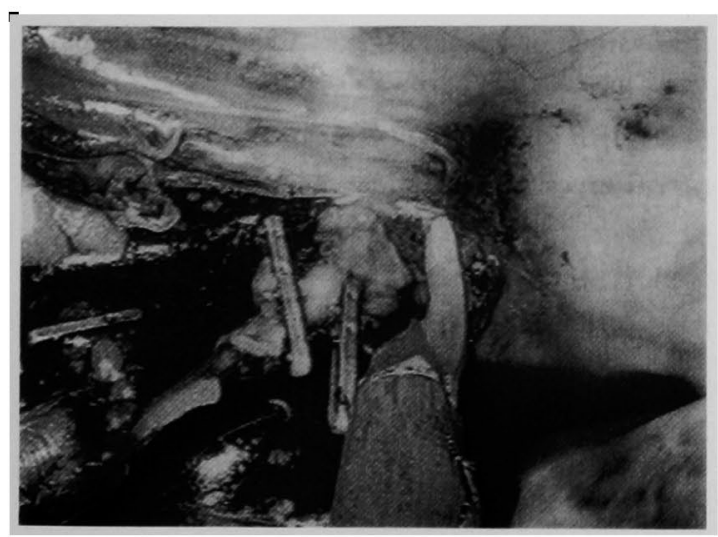

図 2 術中所見：交感神経翰を把持しクリッピング後, 交感神経幹を切除するところ。
において「急性带状疱疹に引き続く，皮膚分節におけ る皮盧の変性を伴う慢性疼痛」と定義されている"．こ れには時間的概念が含まれておらず，どこまでが急性 帯状疱疹による痛みで，どこからが PHN かについて は，1力月， 2 力月， 3 力月， 6 力月などとする説が ある ${ }^{2) \sim 4}$. 現在のところ PHN の発生機序は明らかで はなく，それ故に確実な治療法がないのが現状であり， 多くの治療法が試みられている.今回, 報告した症例 では皮疹出現後 2 力月経過したPHNに対し，その皮 膚分節に対応する下部 (Th 9 ～Th11) 胸部交感神経節 切除が著効を示した。部胸部交感神経節切除は腹部 の癌性難治性疼痛などに行われている(5 が, PHN に 対して行ったという報告は, 検索した限り文献を発見 しえなかった。われわれがこの症例に胸部交感神経節 切除が適応と判断した理由は, 以下のとうりである. まず, PHN に対して胸部交感神経ブロックが効果を 示したという報告はされていう. Colding はVZVが
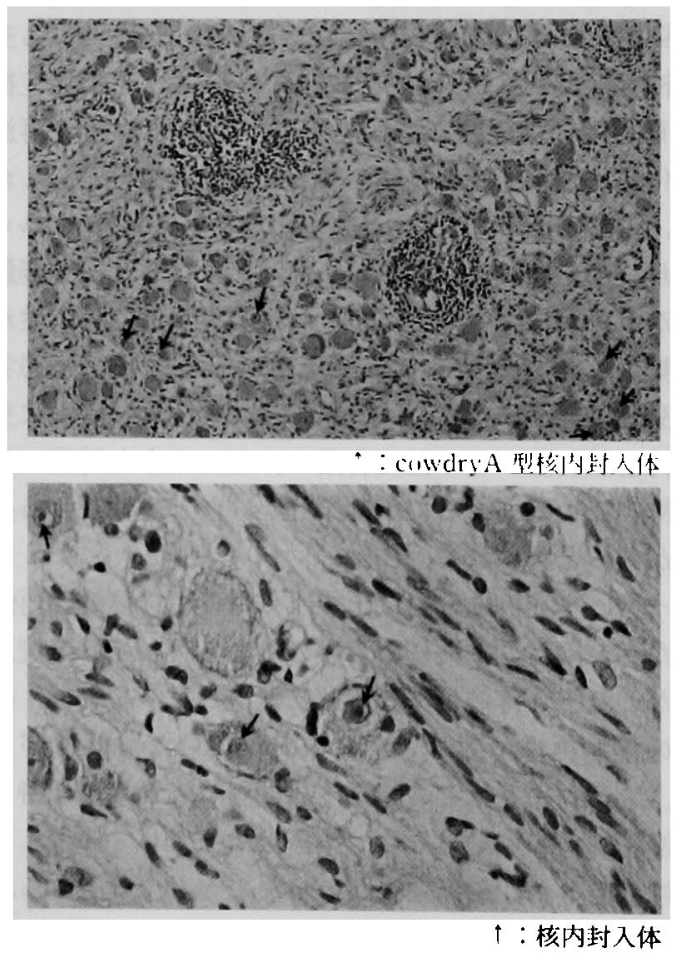

図 3 病理組緎所見：a）：神経節練胞の破壊, 神経 食現象 (neuronophagia) が見られ，リンパ球，形 賈細胞の本簇在伴っている，神経節細胞核内に Cowdry A 型核内封入体を認める（HE 染色 $\times$ 100). b) 神経節細胞核内に Cowdry A 型核内封入 体を認める（HE 染色 $\times 400)$.

$\frac{a}{b}$ 
交感神経節に作用してその緊張を高め，罹患部の血管 収縮や組織の虚血を引き起こすために特有の痛みが起 こると考え,この交感神経節の緊張の高まりを局麻薬 でブロックすることの意義を唱え，交感神経節ブロッ クを実践して良好な成績をおさめた ${ }^{21}$.また，この症例 は術前に皮疮の皮成分節に対応する硬膜外ブロックが 効果を示していた事から，交感神経節の切除範囲とし ては，皮用分節に対応する部位とした. 胸腔鏡下手術 のアプローチで低侵謷で安全に手術が行われるように なり，ブロックや焼灼のみよりも交感神経節切除がよ り確実な効果が期待できるため上記の術式を選択し た。また，本症例では帯状疱疹の皮疹出現上り 2 力月 経過した頃の PHNにおいて交感神経節に Cowdry A 型核内封入体が認められた。これは， $\alpha$ ヘルペスウイ ルスの存在とそのウイルスによる炎症反応を示してい る. $\alpha$ ヘルペスウイルスとは, 単純へルペスウイルス (HSV-1，HSV-2)とVZVである。臨床症状から は, 帯状疱疹は明らかであり, 単純ヘルペスウイルス 感染症症状は，認められないことから VZVによる交 感神経節炎と診断した.一般的にVZVは，水痘発症後 に脊髄後根神経節に潜伏感染し ${ }^{819}$ 種々の要因で再活 性化し，帯状疱疹を発症させると言われている。しか し, 交感神経節にVZVが存在したという報告はない。 われわれが経験した症例から、VZVによる交感神経節 炎が PHN の発生機序に何らかの関与がある可能性が 示唆された.今後さらに症例を重ねて, 他の PHN 患者 に交感神経節にVZV が存在するのか, PHN 患者に交 感神経節切除がどの程度有効か，どのような時期に交 感神経節切除をするのが勍果的か，などを検討する必 要があると思われる。

一方, 本症例において術後 1 力月後頃に疼痛が再燃 したが，同時期に薬疹の治療のためステロイドを使用 したところ，疼痛は薬疹と共に軽快した。これは，術 後の疼痛再燃に対しステロイドが効いた可能性があ る. ステロイドはこの時, 疼痛に対して効果を期待し て使用したわけではなく，薬疹の治療として使用した わけであるが，銷痛効果があったことも十分考えられ る. 交感神経節切除後の疼痛再然に対してステロイド が効果的であるかについては，やはりさらに症例を重
ね, 検討する必要がある.

\section{結 語}

帯状疮疹の皮疹出現より 2 力月経過した帯状疮疹後 神経痛 (PHN) に対して, 胸腔鏡下にその皮成分節に 一致した胸部交感神経節切除を施行し著効した 1 例を 経験した.

本諭文の要旨は, 第775回外科集談会に於いて発表した。

$$
\text { 文献 }
$$

1）新村埧人, 宮崎東洋, 小澤 明編：臨床内科医に 必要な皮庯科学へルペスウイルス感染症. 企画日 本臨床内科医会, 協力日本皮阁科学会, スタンタ ード・マッキンタイヤ, 東京, 1995, p46一-59

2）岡田 弘, 中山裕人, 涌澤玲児：帯状疱疹診療上 の留意点および新しい病期分類と PHN の診断基 準の提唱. 30の大学病院による診断と治療シリー ス, 帯状疱疹の診断と治療. 真興交易医学出版部, 東京, 1998, p 61-62, p 245- 253

3）宮崎東洋, 中村憲子, 徳田秀光: 帯状疮疹後神释 痛. ペインクリニック $17: 517-522,1996$

4) IASP : Postherpetic neuralgia. In: Classification of Chronic Pain (2nd ed.), Mersky, H., Bogduk, N. (eds), IASP Press, Seattle, 1994, p61

5）高橋 毅, 柿田 章, 吉田宗紀他：腹部内葴性疼 痛に对寸る胸腔鏡下内䁍神経切離術。手術 50 ： 2141-2147, 1996

6) 河野 匡, 中島 淳, 竹内恵理保他：胸腔鏡下胸 部交感神経焼灼術機器. 医科器械学 $68: 593-$ 598, 1998

7) Noppen M, Meysman M, D'Haese J, et al: Thoracoscopic splanchnicolysis for the Releif of Chronic Pancreatitis Pain ; Experience of a Group of Pneumologists. Chest 113:528-531. 1998

8) JHIF WORKSHOP 帯状疮疹の疼痛管理, Japan Herpesvirus Infections Forum, トーレラザー ル・マッキャン, 東宗、1999, p34-36

9）吉川哲史： $\alpha$ ヘルペスウイルスの潜伏感染と再 活性化機序。日臨 $58: 51-58,2000$ 


\title{
A CASE OF POSTHERPETIC NEURALGIA ON THE RIGHT LATERAL ABDOMEN SUCCESSFULLY TREATED WITH THORACOSCOPIC SYMPATHECTOMY
}

\author{
Mitsuhiro KAWATA, Tadao SATO, Nobukazu NAKAYAMA, \\ Yusuke FURUKAWA, Hiroaki IMANISHI and Tatsuya KOZUMA \\ Department of Surgery, Yokohama Seamen's Insurance Hospital
}

Postherpetic neuralgia (PHN) is one of the diseases having intractable pain. We report here a case of PHN on the right lateral abdomen successfully treated with thoracoscopic sympathectomy.

A 79-year-old man visuted his home doctor of dermatology because of right lateral abdominal vesicular eruption. He was diagnosed as having herpes zoster and treated with antiviral drugs. His right lateral abdominal pain increased and he could not take enough meal. So he was referred to the hospital. There were exanthema and severe pain within the limited region from Th9 to Th11 on his right lateral abdomen. PHN was diagnosed. Analgesics and continuous epidural block could not control his pain.

We performed thoracoscopic right sympatectomy of Th9 Th1l. Immediately after the operation, his severe pain successfully disappeared. Histologically, many nuclear inclusion bodies of Cowdry's type A were seen in sympathetic ganglia. There were neuronophagia and infiltration of lymphocytes and plasma cells. Sympathetic ganglionitis caused by varicella-zoster-virus (VZV) was diagnosed. 